\title{
Hemoglobin Polymorphism and Morphometrical Correlates in the West African Dwarf Sheep of Nigeria
}

\author{
Polimorfismo de la Hemoglobina y Correlaciones Morfométricas \\ en la Oveja Enana del Oeste Áfricano en Nigeria
}

Akinyemi, M. O. \& Salako, A. E.

\begin{abstract}
AKINYEMI, M. O. \& SALAKO, A. E. Hemoglobin polymorphism and morphometrical correlates in the West African Dwarf sheep of Nigeria. Int. J. Morphol., 28(1):205-208, 2010.

SUMMARY: Red cells extracted from blood samples taken by jugular venipuncture from a total of thirty-six traditionally managed adult West African Dwarf rams and ewes were subjected to starch gel electrophoresis, stained to reveal the activities of different allelemorphs at hemoglobin locus and analyzed. The studies was aimed at examining genetic variation as well as pattern of segregation at the locus and unveil possible association that might exist between the phenotypes and selected zoometrical traits. From the three theoretically phenotypes expected to be produced in the population by the two co-dominant alleles identified, only two: HbAA and HbAB were observed. The observed genotype frequencies conformed to Hardy-Weinberg's equilibrium. Proportion of polymorphic loci was $10.10 \%$ while heterozygosity $(\mathrm{H})$ was 0.218 . Investigation showed that the Mendelian segregation at the loci tested was not congruent with investigated quantitative traits vis-à-vis horn and hair lengths tested. The hemoglobin phenotypes are independent of the traits tested.
\end{abstract}

KEY WORDS: Hemoglobin alleles; West African Dwarf; Metric traits; Polymorphism.

\section{INTRODUCTION}

The West African dwarf sheep (WAD) of Nigeria are of various origins and have been grouped into three types based on morphological and productivity characters. As a result, the population within the southwest Nigeria is considered largely to be homogeneous. However, because indigenous sheep are known to contain higher degrees of variation within than between breed groups, the genetic pool of the resource revealed by electrophoresis needs to be characterized and variability within the variety unveiled.

Hemoglobin, an important erythrocyte protein inherited by co dominance in a Mendelian fashion has been reported to be a useful marker through which many economic traits with which it is associated have been improved in farm animals. Variability at this locus is also analyzed to examine its degrees of association with some visible traits thereby widening the scope of its usefulness as genetic markers such as increasing accuracy of selection targeted at genetic improvement of economic traits within the breed.

Published investigations on the morphometric and visible traits evidences. Variability in the Nigerian Indigenous sheep has been documented by Adu \& Ngere (1979) and Salako (2002). These identified three variants of the WAD sheep throughout the country: Biu, Umuahia and the Southwest variant (WAD sheep). Though each was documented to be largely homogenous, indigenous sheep have been characterized by higher degree of variability within than even between groups indicating their high content of genetic variation and their potentials as main reservoir of unique genes which could be valuable even to the industrialized nations whenever environmental concerns necessitates changes in production system.

The poor documentation in the breed necessitates the investigation of the extent of variation present among them by using tools other than traditional body measurements. More so Evaluation of the variety from Data other than the morphological is scarce. Recent advances in the field of molecular genetics have evolved new procedures for investigating variability among animal populations. These range from elecrophoretic detection of polymorphism of gene products at structural loci to Deoxyribonucleic acid (DNA) analysis. Other procedures such as serological and 
immunogenetic analysis have enhanced the investigations. These procedures are important as they are more precise, have furnished higher levels of genetic variation and localize important loci which can prove to be reliable genetic markers for some economic traits, visible traits and livestock diseases and as such have doubled even as time savers to aid precision in selection for genetic improvement and sustainable productivity. For example, FAO (1988) reported that carriers of hemoglobin A have both demonstrated significant resistance against helminth infections. Due to the better functional properties such as greater affinity for oxygen and higher hemoglobin concentration and packed cell volume (Di Stasio, 1997).

This study focuses on identification of genetic diversity among the WAD sheep of the Southwest Nigeria through electrophoretic detection of polymorphism at hemoglobin locus. It is further intended to investigate the relationship if any between detected hemoglobin variants and some traits in the variety in order to contrast their validity as genetic markers.

\section{MATERIAL AND METHOD}

The animals used for this study were obtained from several small holder flocks selected within the humid southwest Nigeria. Traditional flocks within this area usually average 5 individuals comprising males and females in ratio 1:4. These were extensively managed random mating population where characteristically animals browsed road side plants and settle to kitchen wastes only when available. No particular shelter or even veterinary care is provided. A total of thirty-six animals were used. Sampled animals were adults within breeding age group. An average of five animals was sampled per flock.

Blood collection and preparation. $5 \mathrm{ml}$ of blood was collected from each of the sampled animals by jugular venipuncture into a test tube containing Ethylene Diamine Tetra Acetic acid (EDTA) as anticoagulant and properly labeled. Each blood sample was washed with saline and lysed using distilled water. When the lysate was well separated after standing, it was stored at $-200 \mathrm{C}$ pending laboratory analysis.

Laboratory analysis. The red cell lysate was subjected to electrophoresis in a starch gel (STAGE) medium according to the standard procedure described by Smithies (1955) that was later modified by Boyer \& Hiner (1963). In order of decreasing mobility dictated by the molecular weight of the heterogeneous forms of $\mathrm{bHb}, \mathrm{bHbA}$ and $\mathrm{bHbB}$ were designated in a banding pattern. The resulting frequencies of the allele corresponding to the banding pattern were estimated by direct count.

Morpholometrical characters. Quantitative characters: Hair and horn length were recorded for each sampled individuals. Hair length was obtained by pulling two or more hair fibre from the primary follicle of the right side ineach case. The strands were measured in centimeters with tape and the average recorded. Horn length was also recorded as the distance from the based to the tips of the horn measured along the curved structure. The two horns were measured and the average taken in centimeters. These were recorded according to the sexes and entered into the computer for statistical analysis.

Statistical analysis.Hemoglobin genotype and gene frequencies were estimated as follows:

Since only two alleles (A and B) were detected, then,

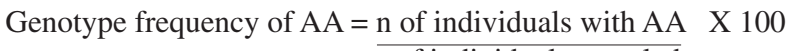
$\mathrm{n}$ of individuals sampled

Genotype frequency of $\mathrm{AB}=\underline{\mathrm{n} \text { of individuals with } \mathrm{AB}} \times 100$ $\mathrm{n}$ of individuals sample Genotype frequency of $\mathrm{BB}=\frac{\mathrm{n} \text { of individuals with BB }}{\mathrm{n} \text { of individual sampled }} \mathrm{X} 100$

Gene frequency of $\mathrm{A}=\mathrm{AA}+1 / 2 \mathrm{AB}$

Total $n$ of alleles

Gene frequency of $\mathrm{B}=\underline{\mathrm{BB}}+1 / 2 \mathrm{AB}$

Total $\mathrm{n}$ of alleles

Heterozzygosity $(\mathrm{H}) \quad=1-\quad \sum^{\mathrm{m}} \mathrm{X}^{-2}$

Where: $\mathrm{i}=$ number of loci involved $(1,2, \ldots \mathrm{m})$

$\mathrm{X}_{\mathrm{i}}=$ frequency of an allele at a locus

\section{RESULT AND DISCUSSION}

The molecular form of the polypeptide fraction of the globin molecule that migrated toward the anode under the electric field was labeled $\mathrm{aHb}$ while the fraction that migrated to the cathode was labeled $\mathrm{bHb}$. aHb was monotypic while 
bHb was polymorphic. The electrophoretic separation of the genetic types of the bHb - hemoglobin showed only two alleles, A and B. Out of he three phenotypes that could theoretically emerge from the two co-dominant alleles, only two was observed in the sample: the homozygote HbAA and the heterozygote $\mathrm{HbAb}$. The frequency of $\mathrm{HbA}$ was higher than that of $\mathrm{HbB}$ being $88.89 \%$ and $11.11 \%$ respectively (Table I). This agrees with the result of Schillhorn van Veen \& Folaranmi (1978) who observed that even when no deliberate selection pressure was applied at the locus. $\mathrm{HbA}$ genotype increases towards the forest zone - where also the WAD sheep investigated in this are predominantly found. This same trend has already been reported in Yankasa sheep for the same region (Tella et al., 2000). In some exotic sheep for example, Lebrijan Churro breed of Andalusia, Rodero et al., (1996) reported phenotypic frequencies of $0.00 \%, 11.11 \%$ and $88.89 \%$ for $\mathrm{HbAA} \mathrm{HbAB}$ and $\mathrm{HbBB}$ respectively while the corresponding figures were $2.17 \%, 20.65 \%$ and $77.17 \%$ respectively for the Grazalema merino sheep.

The population conforms to Hardy-Weinberg's equilibrium Allele frequencies were 0.94 and 0.06 for $\mathrm{A}$ and $\mathrm{B}$ respectively. This demonstrates the predominance of allele A over B in the population. It follows that if bHbA confers genetic resistance to helminth infection as speculated in the West African sheep, the tested population should be resistant although this was not tested in this study. The practice of recurrent selection against allele B could therefore represent a significant reduction in the overall cost of production of mutton. Through a reduced maintenance cost and mortality via helminth diseases
Table II represent the mean and standard deviation of the lengths of hair and horn measured. Results showed sexual dimorphism. This is reflected by the significance of the difference observed between the mean values: $9.27 \pm 4.39$ and $4.84 \pm 1.28$ for hair length of males and females respectively and $10.64 \pm 7.89$ and $0.55 \pm 2.97$ for their respective horn lengths. The associated standard deviations are high and suggest opportunity for improvement of the features through selection within species even when association with $\mathrm{Hb}$ is ignored. More importantly, the longer hair and horns in the rams than the ewe as shown in table 3 corresponds to low frequency of HbAA (0.28) while the shorter hair and horn of the females appears to be related to be related to the higher phenotype frequency of HbAA. It also showed that all the individuals with $\mathrm{HbAB}$ are females. Whether we can claim and attribute higher associate frequency of HbAA to females as observed here is subject to confirmation from further investigation the must use a higher sample size. The relationship among the length and genotypes reported in table 3 further showed that hair and horn length were longer for $\mathrm{HbAA}$ than $\mathrm{HbBB}$ phenotype. There is tentative evidence to show that animals with AA hemoglobin types have longer hair and length. After this relationship is established in further investigation, the genotype (AA) could then serve as marker when selecting for long hair for improvement length especially among sheep breeds whose coast fibres are of relatively high economic importance. HbAA carriers will then play double role because its longer hair combined with genetic resistance to helminth infestation confers upon it a selective advantage when compared with other hemoglobin phenotypes.

Table I. Genotype frequencies of the sampled WAD sheep. $\mathrm{c} 2=1.96 ; 3.84$ ( $1 \mathrm{df}$ and $95 \%$ confidence).

\begin{tabular}{|c|c|c|c|c|c|c|c|c|c|}
\hline & \multicolumn{6}{|c|}{ Hb Phenotype } & \multicolumn{3}{|c|}{ Genotype Frequencies } \\
\hline & $\mathrm{AA}$ & $\%$ & $\mathrm{AB}$ & $\%$ & BB & $\%$ & Total & $\mathrm{A}$ & B \\
\hline Observed & 32 & 88.9 & 4 & 11.1 & 0 & 0.00 & 36 & 0.94 & 0.06 \\
\hline Expected & 33.92 & 2.05 & 0 & 36 & 0 & 0.00 & & & \\
\hline
\end{tabular}

Table II. Mean, standard deviation of quantitative characters and distribution of hemoglobin among the sexes in the WAD sheep. $\mathrm{Hal}=$ hair length; Hol=horn length; $\mathrm{M}=$ male; $\mathrm{F}=$ female $; \mathrm{n}=$ Sample size. Means with different superscripts along the same column are significantly different $(\mathrm{p}<0.05)$.

\begin{tabular}{|c|c|c|c|c|c|c|c|c|c|}
\hline \multicolumn{4}{|c|}{ Quantitative characters $(\mathrm{cm})$} & \multicolumn{6}{|c|}{ Hb Phenotypes } \\
\hline \multirow[t]{2}{*}{ Sex } & \multirow[t]{2}{*}{$\mathbf{n}$} & \multirow[t]{2}{*}{ HaL } & \multirow[t]{2}{*}{ Hol } & \multicolumn{2}{|c|}{ HbAA } & \multicolumn{2}{|c|}{ HbAB } & \multicolumn{2}{|c|}{ HbBB } \\
\hline & & & & Freq & $\%$ & Freq & $\%$ & Freq & $\%$ \\
\hline M & 7 & $9.27 \pm 4.39^{\mathrm{a}}$ & $0.64 \pm 7.89^{\mathrm{a}}$ & 7 & 0.28 & 0 & 0.0 & 0 & 0.0 \\
\hline $\mathrm{F}$ & 29 & $4.84 \pm 1.28^{\mathrm{b}}$ & $0.55 \pm 2.97^{\mathrm{b}}$ & 25 & 0.72 & 4 & 100.0 & 0 & 0.0 \\
\hline Total & 36 & $5.70 \pm 2.51$ & $2.51 \pm 5.84$ & 32 & 0.89 & 4 & 0.11 & 0 & 0.0 \\
\hline
\end{tabular}


AKINYEMI, M. O. \& SALAKO, A. E. Polimorfismo de la hemoglobina y correlaciones morfométricas en la oveja enana del Oeste Áfricano en Nigeria. Int. J. Morphol., 28(1):205-208, 2010.

RESUMEN: Hematíes extraídos de muestras de sangre tomadas por punción venosa yugular de un total de treinta y seis carneros y ovejas enanas del oeste Áfricano, tradicionalmente manejadas como adultos, fueron sometidos a electroforesis en gel de almidón, y analizados mediante tinción para revelar las actividades de los morfoalelos en los diferentes locus de la hemoglobina. El objetivo del estudio fue examinar la variación genética, así como el patrón de segregación en el locus, y develar la posible asociación que puede existir entre los fenotipos y los rasgos zoométricos seleccionados. De los tres fenotipos teóricamente esperados a ser producidos en la población por los dos alelos co-dominantes identificados, sólo dos: HbAA y HbAB fueron observados. Las frecuencias genotípicas observadas se conformaron de acuerdo al equilibrio de Hardy-Weinberg. La proporción de locis polimórficos fue 10,10\%, mientras que la heterocigosidad $(\mathrm{H})$ fue 0,218 . La investigación mostró que la segregación mendeliana en los loci probados no fue congruente con los rasgos cuantitativos investigados vis-à-vis de longitud de cuernos y pelo. Los fenotipos de hemoglobina son independientes de las características de la prueba.

PALABRAS CLAVE: Alelos de hemoglobina; Oveja enana del Oeste; Características métricas; Polimorfismo.

\section{REFERENCES}

Adu, I. F. \& Ngere, L. O. The indigenous sheep of Nigeria. World Rev. Anim. Prod., 15(3):51-62, 1979.

Boyer, S. H. \& Hiner, R. Modified apparatus for starch gel electrophoresis. J. Lab. Clin. Med., 61:879-81, 1963.

Di Stasio, L. Biochemical genetics In: Genetics of sheep. Piper, L. \& Runvisky, A. (Eds), Oxon, CAB International, 1997. pp.133-48.

FAO. Animal genetic resources conservation by management, data banks and Training. FAO Animal production and health paper 44/1. Rome, FAO, 1988. p.186.

Rodero, E. ; de la Haba, M. R. ; Rodero A. \& Herrera, M. Genetics and phenotypic profile of endangered Andalusian sheep and goat breeds. Rome, FAO, 1996.

Salako, A. E. Phenotypic variation among the West African Dwarf and Yankassa sheep of the Humid South-west Nigeria. Ph.D. Thesis, Department of Animal Science, University of Ibadan, Ibadan, Nigeria, 2002.

Schillhorn van Veen, T. W. \& Folaranmi, D. O. B. The hemoglobin types of Nothern Nigerian sheep. Res. Vet. Sci. 25(3):397-8, 1978.

Smithies, O. Zone electrophoresis in starch gels; group variation in serum proteins of normal human adults. Biochem. J., 61:629-41, 1955.

Tella, M. A.; Taiwo, V. O.; Agbede, S. A. \& Alonge, O. D. The influence of hemoglobin types of the incidence of babesiosis and anaplasmosis in West African Dwarf and Yankasa sheep. Trop. Vet J., 18:121-7, 2000.
Correspondence to:

Dr. Salako, A.E.

Animal breeding and Genetics laboratory

Department of Animal Science

University of Ibadan

Ibadan

NIGERIA

Email: aesalak@yahoo.com

Received: 14-02-2009

Accepted: 04-12-2009 